\title{
UDC 1[11.12+40.8+59.9.016+77]
}

\author{
U. I. LUSHCH ${ }^{1 *}$ \\ 1*Danylo Halytsky Lviv National Medical University (Lviv, Ukraine), e-mail ulyana.lushch@ gmail.com, \\ ORCID 0000-0002-3213-595X
}

\section{THE SELF IN THE WORLD: OVERCOMING CLASSICAL DUALISM AND SHAPING NEW LANDMARKS}

Purpose. Based on tracing dualistic tendencies in the history of the concept "self" formation, the paper aims to clarify in what way dualism - contradistinction of the self and sociality, in particular - is being overcome in phenomenological and hermeneutic approaches to the self. Methodology. The systematic and integrative approaches, hermeneutic, phenomenological and retrospective methods, comparative analysis, description and synthesis underlie the research conducted in this paper. Theoretical basis. The development of the concept "self" is traced based on historical retrospective of its definitions. The paper shows the influence of Kantian interpretation of the self upon the contemporary approaches, presents the comparative analysis of the most recent definitions of the self and illustrates the study results on the relation of the self to the body, the world, the narration and the identity with reference to Martin Heidegger, Paul Ricoeur and Charles Taylor in particular. Originality. An integration of phenomenological and hermeneutic approaches to the self is introduced in the paper. It is argued that phenomenological and hermeneutic interpretations can be represented as complementing each other, since they share the anti-dualist perspective and interweave in description of the key aspects of the self, particularly sociality and language. Conclusion. Dualism is overcome in the contemporary interpretations of the self as it is clear from the phenomenological and hermeneutic approaches example. There is no more acute opposition between the self and the world, the self and the body, the self and the social life of a person. The self is considered as "being-in-the-world" which unfolds through intersection of different dimensions: subjectivity, body, temporality, language and sociality. Sociality provides the self with a moral framework through identity and enables conditions for person's self-fulfillment, since the self reaches completeness only by transcending itself towards the others. The modern discovery of the self entails the need to invent a new type of solidarity.

Keywords: self; body; sociality; identity; narrative; good; authenticity; phenomenology; hermeneutics

\section{Introduction}

The contemporaneity is usually described as the period when the Modern mindset has been undermined and the fundamental values have collapsed. Relativization becomes its determinant feature and, in a sense, its destiny. The contemporary person experiences melancholy, apathy, "ennui" and existential discomfort in a crumbled universe of meanings. Driven by the feeling of loss and disorder, the human being has the need to fill the gaps. Metaphysical systems have crashed, a traditional form of religion has been transformed by secularization, social institutions have been compromised - consequently, a person has no solid ground to rely on except oneself, except one's own self. Facing the petrifying, mechanizing and instrumentalizing civilization, a person seeks internal coherence and integrity. Charles Taylor calls the contemporaneity "the Age of Authenticity", inasmuch as since 1960s a philosophical focus has been shifted to person's subjectivity and self. Henceforth, a person rebels against the discipline and limits imposed by the "system", strives "to be oneself", endeavors to discover one's own authentic path (Taylor, 2007, p. 473, p. 476). Personal feelings, personal wealth, personal fulfilment, personal life, personal health, personal privacy, and much else "personal" besides become the major preoccupations of people. Media culture intensifies this tension through dramatization of the real vs. the fake, the natural vs. fabricated (McCarthy, 2009, p. 241, p. 243). By the way, "this gives much of the $20^{\text {th }}$ century human sciences, like psychology and sociology, their subject matter" and make them extremely significant and popular in nowadays (Smith, 1997, p. 49). 
However, the self-orientation, the shift to subjectivity and the pursuit of authenticity often qualify as a mere egoism or an outbreak of hedonism. Personal affiliations seem to be purely instrumental, since they must only satisfy desires and aspirations of one's own self. Such self-centered interpretation of authenticity, on the one hand, and acute social problems of multicultural world entailing discussion on the concept of identity, on the other hand, evoke the need for a careful research on the human self. The questions raised in this respect are: can the human self - and to what extent if it can, indeed - cooperate with others and be open to the others? What is the correlation between selfhood and identity? What is the most adequate interpretation of selfhood to be applied in the contemporary world?

\section{Purpose}

Based on tracing dualistic tendencies in the history of the concept "self" formation, the paper aims to clarify in what way dualism - contradistinction of the self and sociality, in particular - is being overcome in phenomenological and hermeneutic approaches to the self.

\section{Methodology}

The systematic and integrative approaches, hermeneutic, phenomenological and retrospective methods, comparative analysis, description and synthesis underlie the research conducted in this paper.

\section{Presentation of the main material}

Taken for granted contemporary conception of self does not reflect, indeed, some kind of innate human property. The self - according to the formulation of the $20^{\text {th }}$ century anthropologist Marcel Mauss (Hundert, 1997, p. 72) - is "an artefact of a long and varied history of human communities". Human beings of archaic cultures were defined through their belonging to a group; and, surely, emotions or conscience alone could not motivate them, whereas their actions were justified by kinship, descent and status responsibilities deriving from their membership in a particular family clan.

Graeco-Roman philosophical tradition yielded two approaches to interpretation of the self classified by Christopher Gill as "objective-participant" and "subjective-individualist" (Sorabji, 2008, p. 14).

The first one was elaborated in the Classical period by Socrates, Plato and Aristotle. Although there was a range of words for "self" in the Ancient Greek language, their meanings were varying even in the same sentence and there was no single word with a strict definition that we could identify with what we currently understand as "self" (Organ, 1987; Seaford, 2017; Sorabji, 2008). Sometimes the self in the ancient Greek texts is identical with soul or some aspect of soul. In "Phaedo" and "Phaedrus" we find out that Plato, following Socrates, defined soul as immortal and divine, but intellectual rather than spiritual. According to Plato, soul was a rational part of the human being whereby Forms were perceived and known. Hence, the true self, according to Plato, was human reason superior to and separable from the body. Aristotle interpreted soul as the Form of the body - that is the essence of the human being - which was individual for each person and at the same time similar to the Forms of other people. The true self consisted in the accomplishment of this substantial universal human essence that he defined as leading a good life and the good life meant the life guided by reason. Socrates, Plato and Aristotle concurred about the definition of the good life: they agreed that the deployment of the true self was possible exclusively through participation in the life of polis, through fulfillment of civic duties; being a good person was equal to being a good citizen (Raaflaub, 2016; Sihvola, 2008). 
An explicit "subjective-individualist" interpretation originated with Hellenistic philosophers, Stoics to be precise, who discovered the internal world of the human being and separated it from the external social mask that people were condemned to wear. Panaetius distinguished the first persona as a rational being, which was universal and common for all people, and the second persona as individual and the only necessary for making moral decisions. Epictetus referred to prohairesis - will, which he described as the only part of the human being independent of any external authority and completely controlled and enhanced by a person herself. Self-sufficiency of the human being - independence of human self-fulfillment and happiness from any external factors and social participation - was expressed with the concept of autarky. The shift to inwardness resulted from the collapse of the polis and the consequent downgrading of civic values. An abstract notion "person" - for which the self is a core - kept being elaborated in the Ancient Rome where a person was seen as the locus of general rights and duties endowed with conscience and inner life.

In Christianity a person was interpreted as a sacred being, as a possessor of an immortal soul, as the source of autonomous motivation and capability of self-development. As Charles Taylor (1992) formulates "It is hardly an exaggeration to say that it was Augustine who introduced the inwardness of radical reflexivity and bequeathed it to the Western tradition of thought" (p. 131). St Augustine claimed: "in interiore homine habitat veritas" - "the truth lives in the internal man"; he focused on the internal dimension of a human being and defined a true way to the God through self-knowledge, through self-discovery of one's own soul.

In Italian Renaissance the rise of an individual self was reflected in autobiographies and portraits whereby self-awareness and subjectivity were developing. Renaissance humanists singled out four basic components of self: 1) self-knowledge; 2) self-presentation as "giving a good impression of oneself" examined through interest to character types, psychological disorders, simulation and dissimulation (Marsilio Ficino, Fransic Bacon, Robert Burton); 3) uniqueness of an individual and one's independence of definitions through membership; 4) sincerity - the need "to thine own to be true" as Shakespear mentioned in "Hamlet" (Burke, 1997, p. 19).

In the $17^{\text {th }}$ century an increased interest in the concept of self was connected to developments in natural and moral philosophy as well as society and culture in general. While the Middle Ages could be characterized with emotional instability of a person, "oscillation between despair and distracted joy, between cruelty and pious tenderness", as Johan Huizinga puts it (Burke, 1997, p. 19), the consolidation of centralized state in the Early Modernity led to consolidation of the self. The chaos of the religious wars had been overcome and a political stability of the Modern state entailed a psychological stability of a person. Self-control became a subject of examination in a variety of "conduct books". Due to philosophy of Rene Descartes and John Locke the question of person's self was detached from theology and associated with consciousness. Modern definition of the self - that underlies the contemporary Western culture - relied on role distance of the self (that is person's ability to adopt or abandon social roles by will) and autonomy (meaning person's capacity and responsibility to decide on one's own actions and life plan) (Hundert, 1997, p. 73).

Charles Taylor calls this modern version a "buffered self" and traces its origin from secularization and deism. In the Pre-modern and pre-secular age a human being was considered as "porous" that is vulnerable to spirits, demons, cosmic forces and gripped with fear. Illness was explained as a condition of being sapped by sins or possessed by demons (Taylor, 2007, p. 39). Secularization paved the way to deism which reduced God's power to creation of unbreakable natural laws and whereby disenchanted the world. Henceforth, the world was completely ration- 
al, intelligible, scientifically explicable and predictable. In its turn, the scientific picture of the world implied a very different existential condition compared to the pre-modern "porous" one - "buffered" self. Charles Taylor (2007) explains "I can see the boundary as a buffer, such that the things beyond don't need to 'get to me'... The self can see itself as invulnerable, as master of meanings of things for it" (p. 38). The modern "buffered" self is disengaged of everything outside of its mind; it is detached of any external impact and defines meanings and its ultimate purposes within itself. Driven by self-discipline and self-control the "buffered" self prescinds from its own desires, inclinations, compulsions, emotions, and therefore, its actions are completely rational. The "buffered" self is even withdrawn of its own body; the idea of such withdrawal was explicitly formulated in Cartesian dualism. Cogito implies that I know about my thinking with certainty, and thus, thinking is my essence; since bodily nature is not reliable, it cannot belong to my essence which must be incorporeal. Hence, my thinking - which is my self and which constitutes my essence - is independent of my body (Taylor, 2007, p. 285).

Unity and importance of an individual self is affirmed through Cartesian cogito but in a specific manner. Interpretation of the self by Rene Descartes has a scientific form, since it is based on definition of the human being as the subject in its general essence, the subject who is guided by impersonal reason and universal method rules. The purpose of the Cartesian research is a scientific and instrumentally efficient knowledge.

However, there is a contrasting early modern approach to the self - the one formulated by Michel de Montaigne. Montaigne did not examine a sort of general rules, regularities or essential common characteristics of the self; on the contrary, he asserted the necessity to affirm one's own distinctiveness and uniqueness, to acknowledge one's own true needs, intentions and desires conflicting with established common social norms. Montaigne defined self-discovery as aimed at plunging into the depth of one's self, revealing one's own ways of expression, inquiring one's own individual interpretations non-reducible to any general common system. In fact, Montaigne's approach - and not Cartesian one - can be identified among the fundamentals of the Expressivist turn deploying in the $19^{\text {th }}$ century on the grounds of Romanticism. The Expressivist turn marked a shift from the Cartesian disengaged cold self-discipline to post-Augustinian discovery of one's own inwardness, to the need of revealing one's own immense depth and to the urge of self-expression. Within this paradigm, a human being was interpreted as the one with the power of expression and creative imagination, the one with the need to articulate one's own inward source (Taylor, 1992, p. 181, p. 389). The contemporary Age of Authenticity has emerged due to the Expressivist turn, indeed.

The historical review above shows that all conceptions in question share common metaphysical fundamentals: substantialism, essentialism and dualism. The self is defined - explicitly or implicitly - as an independent substance, superior to the body, separate from the body, as the essence of human being, as having definitive role compared to the body. The one who broke this tradition - and, eventually, whose ideas underlie the contemporary reinterpretations of the self was Immanuel Kant (Parasain, 2017).

He defined subjectivity as spontaneous self-activity. The "I think" is a self-activity which is a basic fact of human subjectivity and gives subjectivity its unique ontological character (Kant, 1998, p. 246).

On distinguishing the phenomenal self and the noumenal self, Immanuel Kant (1998) explained that "one can consider the causality of this being in two aspects, as intelligible in action as a thing in itself, and sensible in the effects of that action as an appearance in the world of senses" (p. 535). The empirical self is the object of inner sense, the soul in appearance. The noumenal self is invisible and active of itself. The actions of the noumenal self have effects in 
the sensible world. By definition noumenal self is unknowable and not available for perception, cognition or any insight; however, Immanuel Kant called it the "proper self", a source of morality, personality and intelligence.

He also added a crucial point about the noumenal self (Kant, 1996, p. 99) "Now, a human being really finds in himself a capacity by which he distinguishes himself from all other things, even from himself insofar as he is affected by objects, and that is reason". Therefore, as it follows, the self is unknowable not only because it is a thing-in-itself (noumenon) but also because it is a subject and can never be treated as an object, as a thing. Subjectivity is a fundamentally different ontological category from thinghood.

Søren Kierkegaard also broke with substantialist-objectivist tradition and refuted definition of the self as an immutable entity, a fixed monad, or a substance constituted once and for all. He explained that the self manifested itself through constant relation and becoming, the self consisted in subjectivity and not in something detached and objective. He described the self as a particular self in living interaction with its particular surrounding, life conditions and itself (as self-awareness), as a dialectical relation between opposite poles: finitude and eternity, necessity and possibility. The true self was also interpreted as becoming and as relation to and dependence upon a higher power not through objective thought but through subjective passion (Stan, 2017, p. 47, p. 95).

Summing up the review of genealogy of the self, we can infer that the concept "self" is multidimensional, has a long transformation story and, hence, should be historically and culturally situated.

Kantian and Kierkegaardian interpretations of the self impacted the development of the $20^{\text {th }}$ century conceptions of the self the majority of which share an anti-essentialist orientation. Although, the self is denied at all in analytic philosophy (Sorabji, 2006, p. 17), the two crucial approaches to the self, reflecting the core trends of the $20^{\text {th }}$ century philosophical thought, are phenomenological and hermeneutic ones (Galuschek, 2017, p. 35) that will be examined in more details below. A contemporary Danish philosopher Dan Zahavi explains that according to the phenomenological definition the self is "a dimension that is always already implied in any kind of experience" and according to the hermeneutical definition the self consists in "a constantly changing result of a process of narrative construction of identity" (Engberg-Pedersen, 2008, p. 179).

Nevertheless, some contemporary researchers - as Corey Anton and Richard Sorabji, for instance - claim that we should reconsider the possibility of metaphysics of selfhood, since avoiding metaphysical arguments leads to errors and contradictions. Richard Sorabji (2008) states that a basic metaphysics of the self is to be found in a definition that he suggests: self is "an embodied individual owner who sees himself as me and me again and views the world in terms of its relation to me and me again" (p. 13), where me is considered as individuality, self-awareness and subjectivity. Hence, the self is not an essence, it's an owner (Sorabji, 2006, p. 22). Yet, he emphasizes that social relations and roles (like being a son/father, a teacher/engineer, an American/Italian etc.) - that is, our identities which we build into our selves - are important to our overall picture of our selves but they are not metaphysical and essential, since they keep changing throughout our lives under different circumstances. Speaking of some essential characteristics of the self, interiority, unity and continuity are to be mentioned (Arciero, \& Bondolfi, 2009, p. 32). The self is inward and the variety of its experience keeps being integrated within it throughout a human life. The permanence of a particular self holds in time: the uninterrupted continuity and sameness are always observed between the first and the last stage in the development of an individual, like an oak tree is the same from the acorn to the fully developed tree, or 
a person from birth to death. As Paul Ricoeur (1992) puts it "[T]he ordered series of small changes... threaten resemblance without destroying it" (p. 117).

Due to the self, a human being also cognizes her own experience. Knowledge about herself turns a human being from an observer of the world to an actor in the world: self-discovery and self-knowledge entail self-creation. Hence, man-as-self is both process and product.

Paul Ricoeur stated that the self is specified by the power-to-do; a person is the agent on whom the action depends and who has one's one history (Ricoeur, 1992, p. 113). A contemporary Canadian researcher Henry Venema (2000) concludes likewise that the self is the subject endowed with the power of agency whereas the agency is expressed through (1) speech, (2) action and (3) narration. These three aspects, on the one hand, intersect at some points with and, on the other hand, are complemented by the four interwoven dimensions of selfhood distinguished by Corey Anton (2001): 1) embodiment; 2) temporality; 3) sociality; 4) symbolicity. These mutually complementing classifications draw a holistic picture of the self by combining hermeneutic and phenomenological approaches. Let us take a closer look on them.

A key representative of phenomenological approach to the self Martin Heidegger opposes, like Immanuel Kant, selfhood to thinghood and refutes the Cartesian mind-body and subjectobject dualism. He explains that the initial relation we have to the world is not the one of knowledge about the world as an alienated object. We have, instead, an immediate relation to the world and we can be compared to a craftsman who knows his craft, who knows to do it but is not necessarily capable for a clear explanation of it. We relate to the world as the world of "tools, equipment" we use for our tasks. Alienated reflexion about them as "things" independent of our activities is secondary and derivative. Martin Heidegger coins a term Dasein - "being-there" that is there in the world, "being-in-the-world" - with which the mind-body and mind-world integrity is grasped. Dasein does not allow the distinction between mind or self and the world.

Hence, the self is not a "thinking thing", distinct of bodily experience. Self exists in the world as a lived body here and now, in space and time. The self is "being-in-the-world" and the body enables "being-in-the-world": it is through the body that we perform our activities in the world and interact with others. The self and the body are inseparable (Heidegger, 2010, p. 350). Body is not something I possess; body is not an object of ownership and is not a thing or a property to dispose. Body is a way to be in the world. Such anti-Cartesian interpretation of body is extremely topical in the contemporary Media culture grounded in consumerism and consideration of the body as a marketable commodity, as objectivated and alienated of the self. In nowadays, the body is essential for fashion industry and advertisement; it is exposed to hygienic and therapeutic care, diet and exercising; it is used in medical and pharmaceutical research and commercial enterprises; it underlies the cult of health and eternal youth. The body became an object of consumption, possession and investment: it is considered as something that is supposed to give profit. Under such circumstances, reconsideration of phenomenological interpretation should evoke the reevaluation of the human body and the restoration of person's integrity.

There is no mind or self before or independently of the activity likewise. Dasein is selfconstituting through its self-temporalizing and self-affecting activity. Embodiment and temporality correlate with two fundamental existentials that constitute Dasein and disclose "being-in-theworld": understanding and attunement (Heidegger, 2010, p. 130, p. 155).

"As understanding, Dasein projects its being upon possibilities" (Heidegger, 2010, p. 144). It means to project oneself upon one's possibility of "having the potentiality-for-being-in-theworld", to form or to picture possibilities that the world and one's current situation afford. (Heidegger, 2010, p. 140, p. 283). Understanding entails interpretation; understanding and inter- 
pretation are always to be expressed, and expression is possible by means of language. In forming the horizon of possibilities, Dasein is giving itself a temporal character. Understanding is grounded in the future, whereas attunement temporalizes itself in having-been, since the "nature of mood is a bringing back to" (Heidegger, 2010, p. 162, p. 325).

Attunement means that we always find ourselves in the world through some mood. Being in some mood is a specifically human way of having the world and being in the world. We do not find ourselves in the world as neutral alienated spectators; we rather find ourselves in the world as belonging to it as to a realm of significance and meaning, and thus, moods and attunement constitute a sense of belonging to the world. Dasein expresses its moods (modes of attunement) through body and language: intonation, gesture etc.; and it needs to express itself "not because it has been initially cut off as 'something internal' from something outside, but because as beingin-the-world it is already 'outside'" (Heidegger, 2010, p. 157).

Being-a-self is also revealed through care. Being-a-self means that its own being and the world are always an issue for it; they always matter to it. Martin Heidegger (2010) emphasizes "[H]aving to do with something, producing something, attending something and looking after it, making use of something, giving something up and letting it go, undertaking, accomplishing... considering, discussing" (p. 57) - all these ways of being-in-the-world have concern or care.

Being-in-the-world is also being-with (Mitsein), being-with-others, and thereby attunement implies co-attunement with others. We are "attuned" together in the world: we interact with others, feel empathy and compassion. Our body is what connects us to others. We do not feel the other's pain but we feel it with him and we sense an urge to help him. When someone is afraid it does not mean that we are afraid as well or afraid together, it rather means that we are afraid for him (Heidegger, 2010, p. 111, p. 138).

However, Martin Heidegger clarifies that the self can be authentic and inauthentic. Daily activities and social roles absorb the self and lead to an inauthentic way of being: the self dissolves in the They (das Man). Authenticity, by contrast, can be achieved only through plunging into individuality and solitude - through being-toward-death (each one meet one's death alone and cannot understand it through someone else's death). Being-toward-death enables the reevaluation of life from the finitude perspective and reveals the lostness of Dasein in the They (Heidegger, 2010, p. 241, p. 255).

Hence, as it has just been illustrated, phenomenological approach to the self implies that body and temporality are integral components of the self and this integrity excludes a mere possibility of dualism. Furthermore, Martin Heidegger had added language as a third inherent constituent of the self, and this specification, eventually, branched off as a hermeneutical interpretation of the self outlined here below.

Symbolicity of the self is a linguistic nature of the self. Formation and development of the self are possible exclusively within and by means of a particular language. Language is that whereby a person tells the story of her life and whereby others are inscribed in her life story. Consideration of the self in terms of narrative belongs to the hermeneutic approach, and its key advocates in the $20^{\text {th }}$ century philosophy are Paul Ricoeur and Charles Taylor.

The junction between self and narrative was first made in Stoicism, indeed. Plutarch noted that memories were needed to weave one's life into a united whole, to make a story of one's life holistic (Sorabji, 2008, p. 22). In later centuries, when the future received an outstanding and sacred meaning due to the Biblical concept of the linear history, the future replaced the past in its role of a cornerstone of person's life story.

Understanding of one's life as an unfolding story, as a narrative is based on weaving past, present and future: a human being is permanently changing, becoming different, so the question 
is not only "who am I?" but also "how have I become who I am now?" and "who am I planning to become?". Grasping human life in a narrative means interpreting it as a quest, as a process, as a linear development. Charles Taylor (1992, p. 48) explains it this way "[A]s I project my life forward and endorse the existing direction or give it a new one, I project a future story, not just a state of momentary future but a bent for my whole life to come". So what is crucial here is not the goal of life itself or how close one is to it; it is rather about directedness towards the goal, towards the good and the happy life and one's motivation in regard to them. The goal might be difficult or even impossible to achieve but a key question is about basic orientation towards it, about a gradual process of striving and approaching it.

As it follow from narrative interpretation, the self is not something that we possess as an object independent of our understanding or values, in the same way as we possess organs of our bodies. "But we are only selves insofar as... we seek and find orientation to the good" (Taylor, 1992, p. 34).

Paul Ricoeur points out to the triad "describe, narrate, prescribe" which relates constitution of the action with the constitution of the self. He deduces that there is no ethically neutral narrative because narration - shifting from description to prescription - always requires an ethical framework: "a narrative as an exchange of practical wisdom always includes approval or disapproval of actions, and any evaluation relies on ethical determinations" (Ricoeur, 1992, p. 114, p. 163).

Therefore, narrative interpretation of the self always implies a teleological perspective - the aim to the good life (Ricoeur, 1992, p. 169). A way in which a person defines the good shapes the self. So the self and the good correlate and this correlation is one of fundamentals of the self.

From the first glance it might seem that sociality and self are contradictory concepts, that sociality restricts the freedom of self, deprives it of its individuality and uniqueness, leads it away from its authentic path. Such conclusion is inspired by self-centered, distorted interpretation of authenticity, its fallacy is already acknowledged by the contemporary philosophers, and yet, counter-arguments are not fully articulated.

"The self is social", as Corey Anton (2001) radically states. Along with self-discovery, selfknowledge, self-awareness, self-creation and self-realization all humans - even though to a different extend - are naturally inclined to care about making a good impression on themselves and people who surround them, to care about corresponding socially conditioned standards and norms. Self-image, self-presentation and self-stylization are significant elements of the overall picture of person's self, as they construct "social mask", persona, a set of public roles we all have. Here again, following social norms, standards or traditions does not deprive one's self of its autonomy, uniqueness or authenticity, as long as one uses rationality and autonomous intentionality of acting. A person remains free by doing the same thing as the others if and only if a person acts entirely through herself, meaning if a person understands and rationally grounds reasons and purposes of acting in this particular way inwardly for herself instead of repeating blindly what the others do.

Sociality enables the relation between the world and the self. "[W]e are not simply thrown into social world. We find ourselves undergoing something together" (Crosby, 1996, p. 34). One can be a self only among other selves. One becomes a self due to the others; becomingness of the self is possible only in dialogue; one develops a self, reaches self-definition, self-understanding and selffulfillment only in relation to selves of the surrounding others. It does not necessarily mean that one's self is determined by others, it does not necessarily eliminate autonomy of the self, because one can also define and shape one's self by opposing and resisting the others (Taylor, 1992, p. 35). 
Therefore, "both I [and] others are that through which world is what it is, and also other people are one of the conditions by which I am able to become who I am as I am one of the conditions by which others are able to become who they are" (Anton, 2001, p. 54).

Identity is a condition whereby sociality is manifested. Identity is the sameness among members of a group; it implies a strong notion of group boundedness, an emotionally coloured feeling of belonging to a group, and hence, it eases a fit between the individual and the social. Identity serves as grounds for solidarity and makes collective actions possible. Roger Brubaker and Frederick Cooper (2000, p. 15, p. 20) describe three main components of identity: 1) commonality (sharing the same attributes with other group members); 2) connectedness (the relational ties); 3 ) groupness (the sense of belonging to a group). They distinguish two types of identity based on different modes of its formation. The relational type derives from a position of a person in a relational web, depends on a job or a role an individual plays in relationships (e.g. friend, husband, engineer, student, client etc.). The categorical type of identity is defined by a membership in a class or a category based on sharing the same attributes (e.g. language, gender, ethnicity, religion, citizenship etc.). This latter one is constructed through narratives. "Social life is 'storied'" (Brubaker, \& Cooper, 2000, p. 12), that is, narratives constitute the world in which social actors act. Categorical type of identity usually depends on sharing the same attitude to some events and this attitude along with the interpretation of these events are encoded in narratives.

To identify oneself means to situate oneself in a narrative, to locate oneself in the social reality, and thus, to understand how one is prepared to act. Charles Taylor (1992) indicates the essential link between identity and orientation in moral space. He clarifies that to have identity is to answer the question "who am I?", that is, to be oriented in moral space. On being a Catholic, or a German, or an anarchist, or a teacher, a person defines herself by some moral or spiritual commitments which provide the framework for her to know what is good or bad, what is worth doing, what has meaning and importance for her, what is trivial and secondary. Knowing what is good, significant and valuable orients a person towards happiness, the most admirable way of life (in whatever way it might be defined within different moral frameworks). Charles Taylor (1992) emphasizes that moral orientation is not a metaphysical view we can accept or refute; on the contrary, it is "a condition of being a functional self" (p. 99). The self needs identity insofar as it needs the orientation towards the good, and thus, the happiness.

So, on the one hand, solitude and inwardness are inherent to the self, but on the other hand, the self cannot be fulfilled beyond sociality which at the same time threatens person's authenticity and autonomy. If a person reduces herself to some partial social role and believes that playing this role is the single and sufficient way of gaining her whole reason for being, such a person, eventually, loses her own self (Crosby, 1996, p. 16, p. 22). Identity is contextual, situational, unstable, multiple and fluctuating. Identity is a fragment of the self but it can never fully constitute the self. A person participates in society but she is never a mere element of something complete, or a detail of a mechanism, or an instrument to some higher goal. As Jacques Maritain (1947) claimed "Community is the whole composed of wholes" (p. 47). The person is the subject of rights and belongs only to herself.

Paraphrasing Protagoras: the person lives in the world of which she is the center and the measure; and yet, the person can reach self-fulfillment only through participation in the being of others and orientation towards the good and happiness, that is, only through transcending herself towards the reality beyond herself. "When we deal with persons... we show respect for such beings because of their objective value...then we are transcending ourselves" (Crosby, 1996, p. 178). On respecting the value of others, their dignity and rights, we are transcending ourselves as long as we do not chase our own self-centered interests. 


\section{Originality}

An integration of phenomenological and hermeneutic approaches to the self is introduced in the paper. Examination of different dimensions of the self shows that phenomenological and hermeneutic interpretations of the self can be represented as complementing each other, since they share the anti-dualist perspective and interweave in description of the key aspects of the self, particularly sociality and language.

\section{Conclusion}

The outlining of historical deployment of the concept "self" allows to make a chain of conclusions.

The first one is that dualism is overcome in the contemporary interpretations of the self as it is clear from the phenomenological and hermeneutic approaches example. There is no more acute opposition between the self and the world, the self and the body, the self and the social life of a person. Henceforth, the self is considered as "being-in-the-world" which unfolds through intersection of different dimensions: subjectivity, body, temporality, language and sociality.

Secondly, participation, belonging, identity are no longer regarded neither as a unique determinant of the true self, nor as a distorter of the true self. From the contemporary perspective, sociality complements individuality and subjectivity of the self, provides it with a moral framework through identity and enables conditions for person's self-fulfillment, since the self reaches completeness only by transcending itself towards the others (through care, respect etc.)

Thirdly, the modern discovery of the self obviously brings changes to the social life but does not necessarily lead to self-centered ideology, egoism, rootlessness, isolation and collapse of sociality. It entails, instead, the need to invent a new type of solidarity grounded in the new interpretation of selfhood and person's value.

\section{REFERENCES}

Anton, C. (2001). Selfhood and Authenticity. Albany: State University of New York Press. (in English)

Arciero, G., \& Bondolfi, G. (2009). Selfhood, Identity and Personality Styles. Singapore: Markono Print Media. (in English)

Brubaker, R., \& Cooper, F. (2000). Beyond "Identity". Theory and Society, 29, 1-47. doi: 10.1023/A:1007068714468 (in English)

Burke, P. (1997). Representations of the Self from Petrarch to Descartes. In R. Porter (Ed.), Rewriting the Histories of the Self from Renaissance to the Present (pp. 17-28). London: Routledge. (in English)

Crosby, J. F. (1996). The Selfhood of the Human Person. Washington: The Catholic University of America Press. (in English)

Engberg-Pedersen, T. (2008). Philosophy of the Self in the Apostle Paule. In P. Remes, \& J. Sihvola (Eds.), Ancient Philosophy of the Self (pp. 179-194). New York: Springer. (in English)

Galuschek, A. C. (2017). Selfhood and Recognition: Melanesian and Western Accounts of Rationality. New York: Berghahn Books. (in English)

Heidegger, M. (2010). Being and Time. J. Stambaugh, Trans. Albany: SUNY PRESS. (in English)

Hundert, E. J. (1997). The European Enlightenment and the History of the Self. In R. Porter (Ed.), Rewriting the Self. Histories from the Renaissance to the Present (pp. 72-83). London; New York: Routledge. (in English)

Kant, I. (1998). Critique of Pure Reason. P. Guyer, \& A. Wood (Eds.), Trans. Cambridge: Cambridge University Press. (in English)

Kant, I. (1996). Practical Philosophy. M. J. Gregor (Ed.), Trans. Cambridge: Cambridge University Press. (in English)

Maritain, J. (1947). The Person and the Common Good. J. Fitzgerald, Trans. New York: Charles Scribners Sons. (in English) 
McCarthy, E. D. (2009). Emotional Performances as Dramas of Authenticity. In P. Vannini, \& J. Williams (Eds.), Authenticity in Culture, Self, and Society (pp. 241-255). Padstow: TJ International. (in English)

Organ, T. W. (1987). Philosophy of the Self: East and West. London: Associated University Press. (in English)

Parasain, M. (2017). On Moral Law and Quest for Sellfhood. London: Taylor \& Francis Group. (in English)

Raaflaub, K. A. (2016). Ancient Greece: Man the Measure of All Things. In K. A. Raaflaub (Ed.), The Advanture of the Human Intellect: Self, Society, and the Divine in Ancient World Cultures (pp. 127-148). Chichester: Wiley Blackwell. (in English)

Ricoeur, P. (1992). Oneself as Another. B. Kathleen, Trans. Chicago: The University of Chicago Press. (in English)

Seaford, R. (2017). The Psuche from Homer to Plato. In R. Seaford, J. Wilkins, \& M. Wright (Eds.), Selfhood and the Soul: Essays on Ancient Thought and Literature in Honour of Christopher Gill (pp. 11-32). Oxford: Oxford University Press. doi: 10.1093/acprof:oso/9780198777250.003.0002 (in English)

Sihvola, J. (2008). Aristotle on the Individuality of Self. In P. Remes, \& J. Sihvola (Eds.), Ancient Philosophy of the Self (pp. 125-137). New York: Springer. (in English)

Smith, R. (1997). Self-Reflection and the Self. In R. Porter (Ed.), Rewriting the Histories of the Self from Renaissance to the Present (pp. 49-60). London: Routledge. (in English)

Sorabji, R. (2008). Graeco-Roman Varieties of Self. In P. Remes, \& J. Sihvola (Eds.), Ancient Philosophy of the Self (pp. 13-34). New York: Springer. (in English)

Sorabji, R. (2006). Self: Ancient and Modern Insights about Individuality, Life, and Death. Oxford: Clarendon Press. (in English)

Stan, L. (2017). Selfhood and Otherness in Kierkegaards Authorship: A Heterological Investigation. Lanham: Lexington Books. (in English)

Taylor, C. (2007). A Secular Age. Cambridge: Harvard UniversityPress. (in English)

Taylor, C. (1992). Sources of the Self: The Making of the Modern Identity. Cambridge: Cambridge University Press. (in English)

Venema, H. I. (2000). Identifying Selfhood: Imagination, Narrative, and Hermeneutics in the Thought of Paul Ricoeur. Albany: State University of New York Press. (in English)

\section{LIST OF REFERENCE LINKS}

Anton, C. Selfhood and Authenticity / Corey Anton. - Albany : State University of New York Press, 2001. - 185 p.

Arciero, G. Selfhood, Identity and Personality Styles / G. Arciero, G. Bondolfi. - Singapore : Markono Print Media, 2009. -269 p.

Brubaker, R. Beyond "Identity" / R. Brubaker, F. Cooper // Theory and Society. - 2000. - № 29. - P. 1-47. doi: 10.1023/A: 1007068714468

Burke, P. Representations of the Self from Petrarch to Descartes / P. Burke // Rewriting the Histories of the Self from Renaissance to the Present / Ed. by R. Porter. - London : Routledge, 1997. - P. 17-28.

Crosby, J. F. The Selfhood of the Human Person / J. F. Crosby. - Washington : The Catholic University of America Press, 1996. -319 p.

Engberg-Pedersen, T. Philosophy of the Self in the Apostle Paule / T. Engberg-Pedersen // Ancient Philosophy of the Self / Eds. by P. Remes, J. Sihvola. - New York : Springer, 2008. - P. 179-194.

Galuschek, A. C. Selfhood and Recognition: Melanesian and Western Accounts of Rationality / A. C. Galuschek. New York : Berghahn Books, 2017. - 198 p.

Heidegger, M. Being and Time / M. Heidegger ; Trans. by J. Stambaugh. - Albany : SUNY PRESS, $2010 .-482$ p.

Hundert, E. J. The European Enlightenment and the History of the Self / H. J. Hundert // Rewriting the Self. Histories from the Renaissance to the Present / Ed. by R. Porter. - London ; New York : Routledge, 1997. P. 72-83.

Kant, I. Critique of Pure Reason / I. Kant ; Trans. and Eds. by P. Guyer, A. Wood. - Cambridge : Cambridge University Press, 1998. - 787 p.

Kant, I. Practical Philosophy / I. Kant ; Trans. and Ed. by M. J. Gregor. - Cambridge : Cambridge University Press, 1996. $-669 \mathrm{p}$.

Maritain, J. The Person and the Common Good / J. Maritain ; Trans. by J. Fitzgerald. - New York : Charles Scribner's Sons, 1947. - 98 p.

McCarthy, E. D. Emotional Performances as Dramas of Authenticity / E. D. McCarthy // Authenticity in Culture, Self, and Society / Eds. by P. Vannini and J. Williams. - Padstow : TJ International, 2009. - P. 241-255.

Organ, T. W. Philosophy of the Self: East and West / T. W. Organ. - London : Associated University Press, 1987. 243 p. 
Parasain, M. On Moral Law and Quest for Sellfhood / M. Parasain. - London : Taylor \& Francis Group, 2017. $202 \mathrm{p}$.

Raaflaub, K. A. Ancient Greece: Man the Measure of All Things / K. A. Raaflaub // The Advanture of the Human Intellect: Self, Society, and the Divine in Ancient World Cultures / Ed. by K. A. Raaflaub. - Chichester : Wiley Blackwell, 2016. - P. 127-148.

Ricoeur, P. Oneself as Another / P. Ricoeur ; trans. by B. Kathleen. - Chicago : The University of Chicago Press, 1992. $-363 \mathrm{p}$.

Seaford, R. The Psuchē from Homer to Plato / R. Seaford // Selfhood and the Soul: Essays on Ancient Thought and Literature in Honour of Christopher Gill / Eds. by R. Seaford, J. Wilkins, M. Wright. - Oxford : Oxford University Press, 2017. - P. 11-32. doi: 10.1093/acprof:oso/9780198777250.003.0002

Sihvola, J. Aristotle on the Individuality of Self / J. Sihvola // Ancient Philosophy of the Self / Eds. by P. Remes, J. Sihvola. - New York : Springer, 2008. - P. 125-137.

Smith, R. Self-Reflection and the Self / R. Smith // Rewriting the Self: Histories from the Renaissance to the Present / Ed. by R. Porter. - London : Routledge, 1997. - P. 49-60.

Sorabji, R. Graeco-Roman Varieties of Self / R. Sorabji // Ancient Philosophy of the Self / Eds. by P. Remes, J. Sihvola. - New York : Springer, 2008. - P. 13-34.

Sorabji, R. Self: Ancient and Modern Insights about Individuality, Life, and Death / R. Sorabji. - Oxford : Clarendon Press, 2006. -400 p.

Stan, L. Selfhood and Otherness in Kierkegaard's Authorship: A Heterological Investigation / L. Stan. - Lanham : Lexington Books, 2017. - 248 p.

Taylor, C. A Secular Age / C. Taylor. - Cambridge : Harvard University Press, 2007. - 874 p.

Taylor, C. Sources of the Self: The Making of the Modern Identity / C. Taylor. - Cambridge : Cambridge University Press, 1992. -609 p.

Venema, H. I. Identifying Selfhood: Imagination, Narrative, and Hermeneutics in the Thought of Paul Ricoeur / H. I. Venema. - Albany : State University of New York Press, 2000. - 207 p.

\section{У. І. ЛУЩ ${ }^{1 *}$}

1*Львівський національний медичний університет імені Данила Галицького (Львів, Україна), ел. пошта ulyana.lushch@gmail.com, ORCID 0000-0002-3213-595X

\section{САМІСТЬ У СВІТІ: ПОДОЛАННЯ КЛАСИЧНОГО ДУАЛІЗМУ ТА ФОРМУВАННЯ НОВИХ ОРІЕНТИРІВ}

Мета. Простеживши дуалістичні тенденції в історії формування концепту самості, з'ясувати, яким чином у феноменологічному та герменевтичному підходах до самості долається дуалізм, зокрема протиставлення самості та соціальності. Методологія. Дослідження опирається на синтетичний та інтегративний підходи, герменевтичний, феноменологічний та ретроспективний методи, компаративний аналіз, дескрипцію та синтез. Теоретична основа. Простежено розвиток концепту самості на основі історичної ретроспективи його визначень. Проілюстровано вплив Кантівської інтерпретації самості на сучасні підходи, здійснено компаративний аналіз найновіших визначень самості та досліджено стосунок самості до тіла, світу, нарації та ідентичності на основі праць, зокрема, Мартіна Гайдеггера, Поля Рікера та Чарльза Тейлора. Наукова новизна. У статті представлено інтеграцію феноменологічного та герменевтичного підходів до самості. Доведено, що феноменологічна та герменевтична інтерпретації доповнюють одна одну, оскільки вони грунтуються на анти-дуалістичному погляді на самість та перетинаються в описі основних аспектів самості, зокрема соціальності та мови. Висновки. Приклад феноменологічного та герменевтичного підходів свідчить про те, що сучасна філософія подолала дуалізм у трактуванні самості. Відтепер більше немає гострої опозиції між самістю та світом, самістю та тілом, самістю та соціальним життям особи. Самість розглядається як "буття-у-світі", що розгортається через переплетення різних вимірів: суб'єктивності, тіла, часовості, мови та соціальності. Соціальність за допомогою ідентичності створює для самості моральну систему координат та уможливлює самоздійснення, оскільки самість досягає повноти тільки шляхом трансцендування до інших. Внаслідок модерного відкриття самості виникає потреба винайти новий тип солідарності.

Ключові слова: замість; тіло; соціальність; ідентичність; наратив; добро; автентичність; феноменологія; герменевтика 


\begin{abstract}
У. И. ЛУЩ ${ }^{1 *}$
1 Львовский национальный медицинский университет имени Данила Галицкого (Львов, Украина), эл. почта ulyana.lushch@gmail.com, ORCID 0000-0002-3213-595X
\end{abstract}

\title{
САМОСТЬ В МИРЕ: ПРЕОДОЛЕНИЕ КЛАССИЧЕСКОГО ДУАЛИЗМА И ФОРМИРОВАНИЕ НОВЫХ ОРИЕНТИРОВ
}

Цель. Проследив дуалистические тенденции в истории формирования концепта самости, выяснить, каким образом в феноменологическом и герменевтическом подходах к самости преодолевается дуализм, в частности противопоставление самости и социальности. Методология. Исследование проведено с использованием синтетического и интегративного подходов, герменевтического, феноменологического и ретроспективного методов, компаративного анализа, дескрипции и синтеза. Теоретический базис. Прослежено развитие концепта самости на основе исторической ретроспективы его определений. Проилюстрировано влияние Кантовской интерпретации самости на современные подходы, произведен компаративный анализ самых новых определений самости и исследовано отношение самости к телу, миру, наррации и идентичности на основе работ, в частности, Мартина Хайдеггера, Поля Рикёра и Чарльза Тейлора. Научная новизна. В статье представлена интеграция феноменологического и герменевтического подходов к самости. Доказано, что феноменологическая и герменевтическая интерпретации взаимодополняемые, поскольку основываются на антидуалистической точке зрения на самость и пересекаются в описании ключевых аспектов самости, в частности социальности и языка. Выводы. Пример феноменологического и герменевтического подходов свидетельствует о том, что современная философия преодолела дуализм в трактовке самости. Пример феноменологического и герменевтического подходов свидетельствует о том, что современная философия преодолела дуализм в трактировке самости. Самость рассматривается как "бытие-в-мире", которое разворачивается через переплетение разных измерений: субъективности, тела, темпоральности, языка и социальности. Социальность при помощи идентичности создает для самости моральную систему координат и делает возможной самореализацию, поскольку самость достигает полноты только путем трансцендирования к другим. Модерное открытие самости влечет за собой необходимость изобретения нового типа солидарности.

Ключевые слова: самость; тело; социальность; идентичность; нарратив; добро; аутентичность; феноменология; герменевтика

Received: 06.12.2017

Accepted: 25.03.2018 